\title{
VEČ POZORNOSTI NAŠEMU STROKOVNEMU IZRAZJU
}

\author{
Bi zmogli tudi skupni projekt? \\ (3. nadaljevanje), dr. Zoran Jelenc
}

$\mathrm{V}_{\mathrm{e}}$ žil s svojim prispevkom v AS št. 4/2004, nadaljuje in da je komentar dr. Janka Muršaka v št. 1/2005 konstruktiven in spodbuden za nadaljnjo razpravo, morda tudi zá skupni projekt o našem strokovnem izrazju pri izobraževanju odraslih. Zato jo z veseljem nadaljujem, tokrat le o nekaterih pojasnilih dr. Muršaka, s katerimi se ne strinjam.

Naj začnem spet pri pojmu 'izobraževanje odraslih'. Na nekem posvetovanju mednarodnega združenja za primerjalno izobraževanje odraslih (IACAE), ki sem se ga udeležil pred leti, sem na začetku svojega prispevka izzval začudeno, a hkrati odobravajočo reakcijo (glasen smeh) prisotnih, ko sem jih izzivalno vprašal, ali zanesljivo vedo, o čem se pogovarjamo, ko izgovorimo izraz izobraževanje odraslih (angl. adult education). Vprašanje ni bilo niti najmanj naključno, čeravno je - upoštevajoč to, da je šlo za srečanje vrhunskih svetovnih strokovnjakov za primerjalno raziskovanje andragogike in izobraževanja odraslih - zvenelo nekoliko šaljivo in ali celo predrzno. O pomenu izraza se na različnih območjih sveta - zlasti praktiki, a žal tudi nekateri teoretiki' - razhajajo, to razhajanje pa je lahko tudi precejšnje. Tako 'adult education' v Veliki Britaniji označuje - kot sva tako dr. Muršak kot jaz omenila že $v$ dozdajšnji raz- pravi -, le splošno izobraževanje in praviloma ne vključuje poklicnega, $v$ deželah $\mathrm{z}$ veliko stopnjo nepismenosti jim pomeni predvsem opismenjevanje, $v$ kontinentalni Evropi pa praktično povsod vse izobraževanje »oseb, ki so končale cikel začetnega izobraževanja $v$ otroštvu «(Jelenc, 1991, str. 36). Velika razhajanja o pojmovanju izobraževanja odraslih so se pokazala tudi $v$ naši mednarodni ráziskavi »Znani andragogi o andragogiki« (Jelenc, Svetina, 1993), kjer so se priznani strokovnjaki pri vprašanju, ali pojmujejo izobraževanje odraslih kot celovit (koherenten) sistem ali ne, razdelili na tri skupine: a) na tiste, ki ga ne štejejo za takega, b) na tiste, ki so navajali, da se sistem šele oblikuje, in c) na tiste, ki mu priznavajo sistemsko celovitost, a poudarjajo njegovo pluralistično naravo, pojem pa štejejo - kot se je izrazil Južnoafričan F. Young$\operatorname{man}^{2}$ - za »analizni produkt, ki daje vrsti na videz nepovezanih dejavnosti intelektualno koherenco na ravni globlje strukture « (Jelenc, 2000a, str. 6-7). Dr. Muršak v Pojmownem slovarju (Muršak, 2002, str. 47) res tolerira to različnost in jo tudi $v$ komentarju vsaj deloma pojasnjuje, žal pa se je - po mojem mnenju nekorektno - pri tem geslu, ki je sporno vsaj z zornega kota kontinentalne Evrope, $v$ kateri Slovenci živimo in delujemo, kot ključni pomen gesla ohranil pomen, ki ga ima predvsem 
$\checkmark$ Vcliki Britaniji, ne pa širši, ki ga ima pri nas in $v$ kontinentalni Evropi. Temu se je v svojem mednarodnem slovarju izognil tudi Anglež P. Jarvis (Jarvis, 1990, str: 6-7), ki sicer pri svojem vsakdanjem strokovnem komuniciranju in v praksi uporablja termin 'adult education' $v$ ožjem pomenu, kakršnega ima v Veliki Britaniji, medtem ko za izobraževanje odraslih $v$ širšem (evropskem in severnoameriškem) pomenu uporablja sintagmo "education of adults'. V navedenem mednarodnem slovarju navaja Jarvis več pomenov izraza (tiste, s katerimi ga pojasnjujejo v Veliki Britaniji, ZDA, pri Unescu, na Irskem in Nizozemskem) in za vsakega natančno navede uporabljeni vir. Dr. Muršak bi kot urednik pojmovnega slovarja imel vso pravico, hkrati pa tudi dolžnost, da kot enako pomembna uporabi vsaj dva pomena izraza - na prvem mestu širšcga (veljavnega $\vee$ Sloveniji), to je, da je izobraževanje odraslih »vse izobraževanje oseb, ki so končale cikel začetnega izobraževanja v otroštvu«, potem pa tudi ožjega, ki ga uporabljajo v Veliki Britaniji in mu sicer pripada zgodovinská prioriteta. Ker tega ni naredil, spravlja naše - žal pogosto strokovno negotove in nepoučene izobraževalce odraslih, zlasti praktike $-v$ nepotrebne dvome in jih izpostavlja negotovosti, kateremu pomenu naj dajo prednost.

Drugi izraz, ki menim, da mu moramo nameniti več pozornosti in o njem razpravlja$\mathrm{ti}$, je sintagma 'nadaljevalno izobraževanje', četudi dr. Muršak meni, da vpeljevanje sintagme kot sinonima za pojem 'izobraževanje odraslih' ni potrebno (takega mnenja jc bil že kot konzultativni sodelavec pri pripravi naše izdaje Unescove Terminologije) in »da se pri nas kljub drugačnim prizadevanjem ni prijel « (Muršak 2005, str. 75). Najprej moram oporekati razlııgi, na katero se opira dr. Muršak, ko navaja, da jo povzema po izvirniku (Glossary, 1997), da ne gre za povezavo 'initial - continuing', temveč 'basic - continuing'. Glede tega je Unescova terminologija iz leta 1979, ki smo jo uporabili za podlago naši termino-

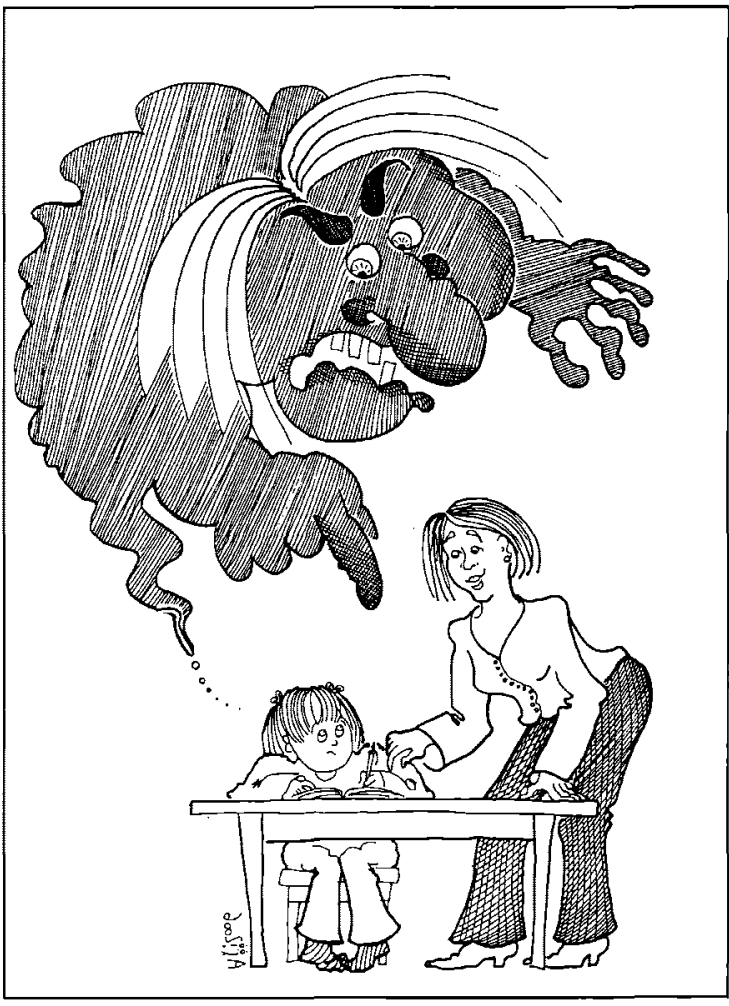

logiji (Jelenc, 1991), povsem jasna in ji kaže zaupati. Avtorji te, Unescove terminologije namreč navajajo, da izraz 'nadaljevalno izobraževanje' odpravlja nejasnost v pojmu 'izobraževanje odraslih', ki izvira iz različnega razumevanja pojma 'odrasli' (primera: študent visokos̆olskega izobraževanja, ki ni prekinil cikla začctncga izobraževanja, ne pripada izobraževanju odraslih, čeravno je biološko in pravno odrasel, adolescent pri l6-ih letih pa je odrasel, čeravno pravno še nima statusa odraslega); pravijo, da »tega odklona (anomalije) ni, če uporabimo izraz 'nadaljevalno' (continuing) izobraževanje«, to pa se začne, ko se konča cikel 'začetnega' (initial) izob- 
raževanja’. ${ }^{4}$ Kontinuiteta je tu povsem jasna in logična, kar pa ni nujno pri kontinuumu 'temeljno - nadaljevalno' (basic - continuing), kjer je bolj logična kontinuiteta 'temeljno - nadaljnje' (basic - further), kar sem tudi shematično pojasnil že v svojem prvem prispevku (Jelenc, 2004, str. 44). Na tem mestu pa se ni smotrno spuščati in poglabljati $v$ to, da ima lahko tudi izraz 'continuing' v različnih območjih več pomenov, na kar opozarjajo avtorji Unescove terminologije (Jelenc, 1991, str. 18 in 45). To, da se izraz 'nadaljevalno' še »ni prijel«, ni nič nenavadnega; novi izrazi se zelo težko "primejo«, še posebno, če jih tudi strokovnjaki in politiki (npr. dr. Muršak, ki je profesor andragogike in kot predsednik Strokovnega sveta RS za izobraževanje odraslih opravlja tudi politično funkcijo) ne uporabljajo radi. Podobno se je godilo izrazu 'vseživljenjsko izobraževanje', ki so ga mnogi, med njimi tudi časnikarji $\vee$ javnih medijih, dolgo časa obotavljaje uporabljali, zdaj pa, ko ga je sprejela in promovirala politika, so ga polni vsi mediji in ga je kar moderno uporabljati. Tako kot je nekomu iskanje novih izrazov zelo izzivalno, je lahko mnogim nepotrebno in moteče. Vsekakor pa se večina na nove izraze zelo težko navadi.

To, da je prevajalka Memoranduma (SEC, 2000), ${ }^{5}$ prevedla izraz 'informal' $z$ 'informalno' (ob tem pa navedla tudi različico 'priložnostno'), ne pomeni niti, da moramo takšen prevod sprejeti, niti da moramo možnost prevajanja navedenega izraza opustiti. ${ }^{\circ}$ Sam sem to možnost iskal in našel izraz, ki ga sicer nismo navajeni, a gotovo ustrezneje označuje pomen angleškega 'informal' kot uporabljeni izraz v Mentorandumu. Jezik je zelo občutljivo torišče človekovega uma, v njem se zrcalijo tudi zelo majhne, celo neznatne in navidezno neopazne razlike med pojmi. Nič ni narobe, da imamo za zelo sorodne pojme različne izraze ali da imamo za enak pojem več izraznih različic. Če imajo $v$ angleščini za najmanj formalizirano učenje dva izraza, to sta 'informal' in 'incidental', zákaj ne bi imeli tudi mi izraza 'aformalno' (za informal) in priložnostno (za incidental)?

Naj to kratko repliko na komentar dr. Muršaka končam z mojim pogledom na »sinhronizacijo terminologije«. Če želimo slovensko izrazje sinhronizirati s tistim, ki ga uporab ljajo drugi jeziki, smo se že na začetku tega procesa dolžni »sinhronizirati« sami med seboj. Prej kot dobesedno prevajanje gesla iz tujega glosarja mora biti opravljena primerjava, kako smo geslo prevajali v naših - resda ne prav številnih - poskusih opredeljevanja strokovnih izrazov. Ne zato, ker sem avtor in urednik naše prve popolnejše terminologije, temveč zato, ker smo z njo ( $s$ pomočjo in $s$ soglasjem uglednih konzultativnih sodelavcev, med njimi je bil tudi dr. Muršak) za potrebe naše strokovne javnosti - trdim da resno in temeljito - opredelili pomene relevantnih strokovnih izrazov. Če z vsakim novim slovarjem te opredelitve spremenimo, vnašamo med uporabnike zmedo in jih spravljamo $v$ negotovost o tem, kateri izraz naj uporabljajo, da bi z njim izrazili to, kar žclijo in kar jim pomeni. Zato se mora vsak avtor in urednik, ki se loteva izrazoslovja, najprej dodobra seznaniti s prejšnjimi terminološkimi rešitvami in opredelitvami, in sc, če želi kaj spremeniti, dopolniti ali izboljšati, posvetovati z uredniki in avtorji prejšnjih poskusov ali celo opraviti širše konzultacije s kompetentnimi strokovnjaki. Ne vem, zakaj tega dr. Muršak ni opravil, in tudi tega ne, kaj je mislil z opombo, da verjame, da $\gg$ dr. Jelenc sebi ni pripisal vloge arbitra«. Č si nekdo prizadeva za čimbolj čisto in usklajeno rabo izrazoslovja, $v$ tem primeru sem bil to pač jaz, to ne pomeni, da si jemlje vlogo arbitra, temveč da opozarja na nekaj, kar ocenjuje kot sporno, nepopolno, neusklajeno in morebiti tudi napačno. Gre za razpravo, ki mora biti tidno argumentirana. Na koncu se zahvaljujem dr. Muršaku za kompliment, da sem poklican, da sprožim pobudo za pripravo »pojmovnega slovarja s celotno 
terminologijo « in da postanem »njena gonilna sila«. To bi res delal $z$ velikim veseljem in zagnanostjo; za to bi prav gotovo našel čas v mojem sicer 'prenatrpanem' upokojenskem urniku. Problem pri tem pa je to, da pri nas upokojenec ne more biti nosilec raziskovalnih in razvojnih projektov (?!), vsaj tistih ne, ki jih financira Ministrstvo za visoko šolstvo, znanost in tehnologijo; kot da upokojeni raziskovalec ne more imeti ustreznega znanja in kompetenc! Zato lahko le pozovem dr. Muršaka - še posebej kot predsednika Strokovnega sveta RS za izobraževanje odraslih - da on postane »gonilna sila« in poskuša najti ustrezno rešitev, $v$ kateri bi me vselilo sodelovati tako $z$ njim kot tudi $z$ drugimi zainteresiranimi in kompetentnimi sodelavci.

\section{LITERATURA IN VIRI}

Jarvis, P. (1990). International Dictionary of Adult and Continuing Education. London: Routledge.

Jelenc, Z. (ur:) (1991). Terminologija izobraževanja odraslih $-z$ gesli in pojasnili $v$ slovenščini ter z gesli $v$ angleškem, francoskem, španskem, nemškem in italijanskem jeciku, (Zbial in uf. Zoran Jelenc). Ljubljana: Pedagoški inštitut pri Univer si v Ljubljani (Zobraževanje odraslih, 6).

Jelenc, Z., Svetina M. (ur.) (1993). Premislek o izobraževanju odraslih in razvoju. Ljubljana: Andragoški center Slovenije.

Jelenc, Zoran (2000a). Nacionalne strategije izobažžatnja odraslih. Andlagoška spoznanja, št. 2, stı. 5-20.

Jelenc, Z. (2000b). Strategija in koncepcija izoblaževanja odraslith v Sloveniji. Ljubljana: Andagoški center Slovenije.

Jelenc, 7. (2004). Več pozornosti našemu strokovnemt izrazju. Andragoška spoznanja, s̆t. 4, str. 40-49.

SEC (2000). Memorandum o vseživljenjskem učcuju. Bruselj: Komisija Evropske skupnosti, 30. 10. 2000 (Delovno gradivo).

Muršak, J. (2002). Pojmovni slovar za področje poklicnega in strokovnega izobraževanja. Ljubljana: Ministrstvo za šolstvo in šport - Urad RS za šolstvo in Center RS za poklicno izobraževanje.

Muıšık, J. (2005). Komental k prispevku »Več pozornosti našcmu strokovnemu izrazju« alt kako do poenotenja raznolikega. Andingoška spoznanja, 1, str. 74-76.
' labraževanje odraslih je dejanost, ki se je v swojem razroju izrazito ramala po praktičnih potrebah, zato se je morala prilagajan trenumim razmeram, w ten procesit pa proviloma ni iskala niti potrebenala skupnih teoreticunh izhodišc in modelon (vec o tem selenc, $2000 a$, str: 7).

2 Jelenc, Suetina, 1993, str. 287.

'Izumi naslow je Terminology of Adult Education, $P a$ ris, 1979, izdal jo je Unesco, delo pa je rezullat nekajlethega timikega dela stirih avtorjer, isakega z drigega območja in jezikonnega podmója: a angleščino Colin Titums is V. Britamije, za fraucoščino Paul Lengrand is Francije za serernoameriške angleške izraze in španšci. no Diana Konside iz ZDA in Paz Buttedahl iz Kanade; izrina Unexcora terminologija je trijezichna, nemške izraze sem kot trednik nas̆ega prevoda dodal jaz.

+Timus ben sujih razpra navaja tudi tako absarden primer, da je iahko po leljanni opredelin iermina 'izobraževanje odraslih" potencialni udeleženec lega izolmraževanja celo deseslemi orok, ki je koncal sačctno izobraževanje po 3. razredu osnome sole; bsekakor se manj nenatadno stǐ̌i, č rečemo, da posfane potem potenciahn adelešenec 'nadaljevalnega izobraževanja'.

${ }^{5}$ To je direktorica Andragoškega centra d: Vida A. Mohorčč Spolar, ki sicer odlicho obvilada angleřcino.

"Pri prevajanju mojh besedil sem inel s prevajalci ž indi selo neugodne izkus̆nje. Toko se mi je zelo neugodno wismilo ysponin, ko mi je sicer zelo dobra prevajalka prevedh izraz 'nonformal education' z 'nefornalno solanje'; dobra poznavalka ans/escine zant ni dotolj dobro poznala ali razlimeda andragogike.

7 Več o razlikotanju med njima glej v Jelenc, 2000b. str: 85-86, "tisku pa je andi moj prisperek za rematki del o useživljenjskem izobraževanju „Vsez̆iljenjsko wenje - za zdaj promoviranje bolj kot sistemsko urejanjes veni od nasledijih stevilk Sodobne pedagogike, lemik 2005 , kier to pojasnjujem. 